УДК [159. 9 + 37]: 001

DOI: https://doi.org/10.35619/iiu.v0i9.138

Бондарець Марія здобувач $\mathrm{PhD}$ за напрямом 011 «Освітні, педагогічні науки» Рівненського державного гуманітарного університету, м. Рівне, Україна ORCID: 0000-0001-9027-8652, e-mail:maria_2812@ukr.net

\title{
ЗМІСТОВЕ НАПОВНЕННЯ ПОНЯТТЯ «МОРАЛЬНО ДЕФЕКТИВНИЙ» В ПСИХОЛОГО-ПЕДАГОГІЧНІЙ НАУЦІ КІНЦЯ ХІХ - ПОЧАТКУ ХХ СТОЛІТТЯ
}

Анотація. На основі аналізу поглядів відомих педагогів, психологів, педологів кінця XIX - поч. XX ст. (I. А. Арямов, П. Г. Бельський, П. П. Блонський, Л. С. Виготський, В. П. Кащенко, Н. К. Крупська, А. С. Макаренко, В. Н. СорокаРосинський, Н. Тарасевич, Г. Трошин, Г. А. Фортунатов та ін.) розкрито змістове наповнення поняття «морально дефективний».

3'ясовано, що досліджуваним поняттям характеризували дитину 3 поведінкою, що не відповідала нормам суспільної моралі. До категорії «дефективних» зараховували і малолітніх злочинців, і сотні тисяч безпритульних, які опинилися на вулиці унаслідок соціальних катаклізмів. «Морально дефективними» дітьми вважали велику й неоднорідну групу, представники якої відрізнялися від бажаної норми у своєму розвитку й поведінці.

Вітчизняні педагоги, психологи, педологи (П. Бельский, В. П. Кащенко й ін.) теорію моральної дефективності вважали біологізаторською за своєю суттю, відповідно, такі здібності, як засвоєння й виконання моральної норми визнавалися ними вродженими, а відхилення у поведінці, правопорушення розглядалися як результат генетично зумовлених дегенеративних процесів, що можуть посилюватися або ж послаблюватися під впливом навколишнього середовища.

Натомість， П. П. Блонський， Л.С.Виготський， Н. Тарасевич， В.Н.СорокаРосинський й ін. розглядали моральність як складне явище, що має не біологічне, а соціальне коріння. Прихильники соціологізаторської теорії причини моральної дефективності пояснювали соціально-економічними та культурно-педагогічними умовами, у яких росла дитина. Психологічні проблеми таких дітей інтерпретувалися як наслідок стресів, що виникали в результаті війни, революції й радикальних змін, через які пройшло покоління дітей досліджуваного періоду.

На початку 30-х pp. XX ст. у контексті державної політики вчені практично припинили вживання поняття «морально дефективні» як ідеологічно проблематичне для позначення дітей 3 різноманітними порушеннями, натомість, почали активно використовувати поняття «важкі» діти.

Ключові слова: «морально дефективний», «moral insanity», «дефективні» діти, «важкі» діти, біологізаторська теорія, соціологізаторська теорія.

Постановка проблеми. Виклики сучасного суспільства: війна, матеріальні негаразди, зростання кількості неповних сімей, дитяча бездоглядність, зміни в державних i економічних структурах, світогляді, життевих цінностях обумовили кризу освіти, охорони здоров'я, науки, культури, що відобразилося на якості життя підростаючого покоління, призвело до збільшення чисельності «важких» дітей, вихованців 3 
відхиленнями в розвитку, до росту безпритульності й злочинності серед дітей $\mathrm{i}$ підлітків. Згідно з офіційними даними статистики, на сьогодні в Україні налічується більше двадцяти семи тисяч безпритульних дітей, а реально їх значно більше. Спостерігається тенденція до зростання частки неповних сімей в Україні близько 2,3 млн. сімей, в яких дітей виховує переважно мати, котра зіштовхується 3 багатьма проблемами, зокрема i працевлаштуванням. Малозабезпеченими на сьогодні залишаються 118,2 тис. сімей (Державний інститут розвитку сім’ї та молоді, 2010). Тому на сучасному етапі розвитку демократичного суспільства особливого значення набуває формування та реалізація адекватної соціальної політики стосовно «важких» дітей як запоруки ефективного розвитку держави. Це передбачає не лише запровадження системи педагогічних, медичних, соціальних заходів, спрямованих на допомогу дитині у кризових ситуаціях, а й вивчення кращого досвіду виховання таких дітей в історико-педагогічній ретроспективі. Особливо актуальними у контексті проблеми дослідження є напрацювання в галузі освіти кінця XIX - початку XX ст., коли соціокультурна ситуація в країні була досить складною і проблема виховання «важких» дітей, як їх часто називали «морально дефективних», була пріоритетною.

Нині термін «морально дефективні» сприймається досить неоднозначно, тому виникла потреба розкрити його змістове наповнення через призму тієї доби, коли ним активно послуговувалися педагоги, психологи, педологи.

Тому мета пропонованої розвідки полягає у визначенні змісту поняття «морально дефективні» крізь призму поглядів відомих педагогів, психологів, педологів кінця XIX - початку XX ст.

Аналіз останніх досліджень із проблеми. Вивченню поведінкових відхилень у дітей, а також їх моральних особливостей були присвячені роботи О. Белічева, М. Гернета, Я. Гілінського, К. Лебединської, А. Лічко, Н. Максимової, І І. Невського, М. Раттер, Л. Славіної, В. Степанова, Д. Фельдштейна, Т. Шульги та ін. (Раттер, 1987; Степанов, 2001; Шульга, 1993). Проблему «моральної дефективності» в історико-педагогічному контексті вивчали Н. Дічек, В. Цвєтков, Т. Янченко та ін. (Дічек, 2013; Янченко, 2014).

Виклад основного матеріалу дослідження. Термін «морально дефективний» вперше був уведений англійським ученим Д. Прітчардом у 1835 p. і означав моральне божевілля (moral insanity) - психічну хворобу, що пов'язана лише із моральною сферою й не зачіпає інтелект (Байфорд, без дати). У Великобританії поняття «розумової дефективності», а також «моральної дефективності» використовувалися в контексті «Закону про розумово відсталих» (1913 р.). Теоретична передумова цього вчення - теорія моральності так званої шотландської школи. Плеяда шотландських філософів XVIII-XIX ст. дуже докладно розробила теорію про особливе властиве людині моральне почуття й вроджені моральні ідеї. Це моральне почуття вважалося вродженим у людині, подібно інстинкту або будь-якому органу чуттів - зору, слуху й т. п. На грунті цієї теорії «морального почуття» розвинулося вчення про вроджений моральний інстинкт і вроджені моральні ідеї. Як зазначав П. Блонський, 3 іншого боку, «Прітчард звідси ж вивів moral insanity: як бувають сліпонароджені, позбавлені чуття зору, як бувають глухі, позбавлені чуття слуху, так бувають люди, сліпі й глухі до добра, нечутливі до добра, позбавлені «морального почуття». Це буквально «моральні виродки». Ось така 
давня передумова лежить в основі теорії про «моральну дефективність» (moral insanity)» (Блонский, 1979).

Теорія моральної дефективності була біологізаторською за своєю суттю, відповідно до неї такі здібності, як засвоєння й виконання моральної норми визнавалися вродженими, а відхилення у поведінці, правопорушення розглядалися як результат генетично зумовлених дегенеративних процесів, що можуть посилюватися або ж послаблюватися під впливом навколишнього середовища (Бельский, 1924). Цієї теорії дотримувалися такі видатні європейські вчені, як французький соціолог Е. Дюркгейм (1902), німецький психіатр Е. Крепелін (1906), швейцарські психіатри і психологи Е. Блейлер (1911) і К. Г. Юнг (1912).

Відомий вітчизняний психіатр В. П. Кащенко наявні у дітей порушення називав фізичною дефективністю, душевною недостатністю, які розглядав як певні відхилення від норми в тілі чи в душі дитини, але те й друге разом називав «тіньовим боком цивілізації» (Кащенко, 2005). Говорячи про «ознаки дефективності», В.П.Кащенко орієнтував звертати увагу на те, як дитина починає навчатися у школі, оскільки ознакою розумової відсталості вважав погане засвоєння навчального матеріалу. Але недостатнє засвоєння навчального матеріалу на початковому етапі навчання може бути внаслідок затримки психічного розвитку або педагогічної запущеності, хвороб, недостатньої адаптації дитини до умов шкільного навчання. У юнацькому віці ознаками дефективності вчений вважав моральну зіпсованість, прагнення до бродіння, жорстокість, які називав тимчасовою дефективністю або дефективністю, що здається, ввижається (Кащенко, 2005, с. 35). В. П. Кащенко вважав, що «дефективність, взята в широкому смислі слова, включає в себе розумову дефективність, дефективність характеру i антисоціальність» (Кащенко, 2005, с. 41). Під дефективністю у юнацькому віці він вбачав порушення поведінкових норм. Учений використовував сам термін «дефективна дитина» у назві, яку дав своїй школі-санаторію, відкритому в 1908 р., що й діагностував для дітей із широким спектром когнітивних порушень і поведінкових проблем, більшість із яких були досить легкими.

У доповіді «До питання про виховання і навчання дефективних дітей», яку В. П. Кащенко виголосив на III з'їзді російських психіатрів у 1912 р., учений оприлюднив власну класифікацію порушень у дітей, в якій виділив типи дітей, відрізняючи дітей з розумовою й моральною недостатністю від дітей із фізичною дефективністю. Діти 3 розумовою й моральною недостатністю склали 4 типи. До 1 типу увійшли субнормальні діти, до яких автор відніс «дебілів, імбецилів, закінчуючи ідіотами»; до II типу - діти 3 психічною нестійкістю, так звані важкі діти; III тип склали епілептики 3 підгрупою нервово хворих; IV тип - психічно хворі діти (Кащенко, 1992, с. 214). В. П. Кащенко вважав, що спадковість, хвороби і середовище - три головних чинники дефективності; він переконував, що моральну дефективність можна знищити правильним вихованням.

Дитячий психіатр, педолог, дефектолог Адріан Грибоєдов, вивчаючи «дефективних» дітей, обгрунтовував принципи виховання і навчання їх в сім’і $\mathrm{i}$ школі (Грибоедов, 1924).

Натомість, відомий російський учений Г. Трошин в праці «Антропологические основы воспитания - сравнительная психология нормальных и ненормальных детей» (1915) роз'яснював: «Моральне божевілля 
- це потрясіння розуму, яке впливає винятково на моральні почуття, залишаючи інтелект зовсім неушкодженим. ... У подальшій історії психіатрії moral insanity дуже зблизилося 3 недорозвиненням. Причин для цього було цілком достатньо: обидві форми мають загальну етіологію, головним чином спадкові впливи; moral insanity часто буває вродженим і стаціонарним станом, як і різні форми розумового недорозвинення. Мимоволі впадає в око аналогія між ними: моральний ідіотизм в паралель розумовому. Природно, що, зрештою, стали доводити неточність первісної формули Прітчарда («неушкоджений інтелект»), і в цей час більшість (але не всі) психіатри притримуються тієї думки, що при moral insanity розумові здібності знижені. Отже, зниження кваліфікують як «легке», «слабке», «ледь помітне» і т. п.» (Трошин, 1915, с.541). Г. Трошин вважав, що основними ознаками морально дефективних дітей $є$ різкий егоїзм і гіпертрофія особистості, яка проявляється впертістю, свавіллям, непіддатливістю зовнішнім впливам, непристосованістю до зовнішнього середовища (навчальні заклади). Найважливіший симптом в moral insanity - так звані викривлені почуття й потяги: до неправди, злодійства, підпалів, жорстокості до близьких людей, катування тварин, онанізму, цинізму, буйству, взагалі до всього дурного (там само).

У 20-ті pp. ХХ ст. одеський лікар, професор медицини М. Тарасевич звернув увагу на існуючі класифікації дітей з порушеннями розвитку, оскільки «питання про дитячу дефективність набуло державного значення» (Тарасевич, 1922). 24 березня 1921 року М. Тарасевич виступив 3 доповіддю на науковій конференції Одеського Педологічного інституту на тему «Класифікація дефективних дітей», у якій значну увагу приділив класифікації 3 суто симптоматичними формами: «моральні аномалії», «здатність до брехні», «неслухняні діти» (Тарасевич, 1922, с.13).У запропонованій лікарем класифікації в кожному з типів дитячої дефективності було виділено дітей трьох груп: а) без розумової і моральної дефективності; б) 3 розумовою дефективністю; в) з моральною дефективністю (Тарасевич, 1924).

Для розуміння сутності поняття «морально дефективне» дитинство безперечно інтерес становлять роботи видатного педагога, психолога, педолога П. П. Блонського. Учений розглядав поняття «морально дефективний» у праці «О так называемой моральной дефективности» (1923), вважаючи, що моральна дефективність - «це легка розумова відсталість: легка - це значить, виражаючись технічно, не медична, не клінічна, але педагогічна. Виражаючись популярно, це не «хвора», але педагогічно запущена дитина. Безпритульна дитина - імморалик - це найчастіше просто педагогічно запущена дитина, настільки запущена, що в неї ще немає такого розумового розвитку, який потрібно для усвідомлення соціально-моральних відносин і норм і правильного орієнтування в співіснуванні» (Блонский, о так називаемой). На переконання педолога, «теорія «моральної дефективності» є дуже шкідлива, оскільки вона благословляє педагога, без усякої підстави, стверджуючи про дитину, умиваючи свої руки: «Це - безнадійна дитина, і виховувати іiі ні до чого». Замість того, щоб розумово розвивати таку дитину, їі відсилають в будинки дефективних дітей, дитячі клініки...» (Блонский, 1923). П. П. Блонський був переконаний, що «дитина здорова: вона тільки педагогічно запущена, розумово не цілком дорозвинена. Відповідно й треба ії виховувати як здорову запущену дитину. Але взагалі, особливо там, де ми маємо справу з консервативним педагогічним персоналом, треба насамперед перевірити, чи насправді $є$ ця 
імморальність дитини, чи не продукт вона фантазії педагога, що погано розбирається в психології нової дитини» (Блонский, 1923).

Таким чином, педолог завдав серйозного удару по теорії «моральної дефективності». П. П. Блонський стверджував, що діагноз розумовому розвитку дитини може ставити лише спеціаліст. У випадках відсутності клінічних реальних хвороб педагоги мають справу 3 «педагогічною занедбаністю». В усіх випадках, коли дитина проявляє відхилення в поведінці, необхідно, на думку П. П. Блонського, зрозуміти сутність цих відхилень, виявити їх причини і створити умови для подолання недоліків. Це твердження базується на тому, що П. П. Блонський розглядав моральність як складне явище, що має не біологічне, а соціальне коріння.

Відомий психолог, педолог Л. С. Виготський на Першому німецькому конгресі з лікувальної педагогіки (1922) підтримав тих доповідачів котрі критикували концепцію Moral insanity (моральної дефективності) як душевну хворобу, а розуміли іiі як «випадіння тих чи інших цінностей чи оцінок, наприклад, мотивів поведінки, мотивів цінностей, які зустрічаються i в нормальних людей ... їх необхідно шукати не у вродженому дефекті волі чи збоченні окремих функцій, але й в середовищі і вихованні. Як недолік морального виховання» (Выготский, 1983 a, с. 151). Л. С. Виготський обгрунтовував доцільність використання термінів «важка дитина», «важко виховувана дитина», замість «морально дефективна дитина». Коментуючи основні положення плану педагогічно-дослідницької діяльності 3 питань важкого дитинства у 1929 році, зазначав: «Ми виділили такі типи і види важких дітей, які підлягають вивченню: важкі діти в масовій школі, важковиховувані діти в самому смислі цього слова (безпритульні, правопорушники, педагогічно занедбані), психо-невропатичні діти, розумово відсталі, сліпі, глухонімі, логопати, психічно і фізично хворі діти» (Выготский, 1983 b, c. 193).

У працях П. Блонського, Л. Виготського, Н. Тарасевича причини моральної дефективності пояснювалися соціально-економічними та культурнопедагогічними умовами, у яких росла дитина (Блонский, 1924; Выготский, 1983 а; Тарасевич, 1924). Вони доводили, що в іншому середовищі, сприятливому для дитячого розвитку, «важка дитина досить швидко втрачає риси моральної дефективності й стає на новий шлях» (Выготский, 1983 а, c.150).

Отже, можемо стверджувати, що питання моральної дефективності розглядалася в педології як проблема середовища, «оздоровлення якого стало основою виховної практики в цій сфері».

Своєю чергою, відомий педагог, директор школи для важковиховуваних дітей ім. Ф. М. Достоєвського в тодішньому Петрограді Росинський ще більше критикував практику використання термінів «важкий» $\mathrm{i}$ «морально дефективний» як синонімів (Сорока-Росинский, 1991). «Морально дефективним», $з$ точки зору В. Н. Сороки-Росинського, вважався вихованець, який мав виражені проблеми в особистісному розвитку. Для розмежування поняття «важковиховувані» та «морально-дефективні» педагог пропонував: «Зазвичай прийнято змішувати ці категорії дітей, об'єднуючи їх під загальною назвою дефективних, і з зовнішнього боку таке об'єднання здається повністю закономірним - адже насправді кожна дефективна дитина $\epsilon$ важковиховуваною, а кожна важковиховувана від того і важка, що має певний 
дефект». I далі: «Та чи інша дитина може виявитись важкою зовсім не через певний дефект зокрема, а навпаки, важковиховуваність може бути спричинена складністю і багатогранністю натури ... сильні і талановиті люди часто розвиваються дуже бурхливо... найбільш видатні у всіх сферах життя люди дуже часто бували горем для батьків і вихователів - достатньо прочитати їх біографії, щоб впевнитись у цьому...» (Сорока-Росинский, 1991, с.137).

Вважаючи термін «важковиховуваний» недостатньо точним, В. Н. Сорока-Росинський запропонував замінити його висловом «відхилення від норми». 3 огляду на це, педагог виділяв декілька категорій дітей 3 відхиленнями від норми. 1) денормні - безпритульні, педагогічно-занедбані діти, також вихованці $з$ емоційними та вольовими розладами конституційного походження (невротики, істерики та ін.); 2) субнормні або дефективні діти, за виключенням морально дефективних та розумово відсталих; 3) супранормні або обдаровані вихованці (Сорока-Росинский, 1991).

У статті «Важковиховувані» В. Н. Сорока-Росинський переконував: «Нi, важковиховуваність не завжди означає дефективність, не говорячи про гострі випадки фізичної та розумової дефективності, дуже багато дітей найрізноманітніших категорій вважались важковиховуваними лише тому, що в школі загального типу вони викликали труднощі, але ось виокремили розумово відсталих, виокремили морально дефективних, потім невропатів, які потребують медично-педагогічного впливу, потім переростків. I все ж після виокремлення всіх цих дітей наявний певний залишок, який готові визнати якоюсь особливою категорією, що є відмінною від усіх інших, вище згаданих, але який, з іншого боку, намагаючись визначити більш докладно знову готові змішати з усією масою важковиховуваних, із якої він був виокремлений через те, що діти, які належать до цього недостатньо диференційованого виду важковиховуваності, мають схожі 3 іншими іiі видами риси» (СорокаРосинский, 1991, с.142).

У 1923 р. термін «морально дефективні» був гостро розкритикований Н. К. Крупською у праці «О так называемой моральной дефективности» (Крупская, 1932). Вона стверджувала: «Є загнані в кут, озлоблені, замордовані, хворі діти, які довгий час жили в тяжких умовах, в атмосфері розпусти, але немає морально-дефективних» (Крупская, 1923, с.53). Н. К. Крупська підтримала позицію П. П. Блонського: «Ганебний термін «моральнодефективний», що розв'язує руки безсовісної й несвідомої частини педагогів, повинен бути «вигнаний із вжитку ... Безпритульні, занедбані, хворі діти повинні стати рідними, любимими дітьми Радянської республіки» (Крупская, 1923, с.53).

У цей же час педолог І. Арямов (1924) роз'яснював: ««моральнодефективні» - це, передусім, бездоглядні діти, які знаходилися під впливом особливих соціальних норм та потреб, які не відповідали загальносуспільним нормам. Крім того, у таких дітей домінують безумовні рефлекси - самозахист, харчування та інші, які для них законним шляхом не досяжні, а тому у них формується асоціальна поведінка «морально-дефективної дитини» (Арямов, 1924, c. 53).

Своєю чергою, відомий педагог А. С. Макаренко довів, що сутність проблеми важкого дитинства полягає у дефективності стосунків, які утворюються між особистістю та суспільством. На думку педагога, дефективність стосунків виявляється у трьох основних галузях: 1) мотивація 
привласнення (безпосереднє привласнення, потреба, жебрацтво, опосередковане привласнення); 2) мотивація переважання (неорганізована та організована перевага); 3) мотивація відособлення (мотивація початкового егоїзму, мотивація свободи особистості) (Макаренко, 1983, с. 54). Внаслідок цього, конфлікт відображається у правопорушенні, недисциплінованості, асоціальній поведінці. Характерні особливості важкого вихованця формуються як відгук та компенсаторна реакція на життєві обставини, 3 якими зустрічається дитина. Однак і така дитина, окрім негативних особистісних якостей, має й велику кількість позитивних особливостей.

Дослідження психолога Г. А. Фортунатова (1935) підтверджують розуміння сутності важковиховуваності, висловлене А. С. Макаренком. Г. А. Фортунатов зазначав, що важкий учень - не $\epsilon$ «морально-дефективним», він стає таким унаслідок несприятливих умов життя й виховання. Важка дитина характеризується такими проявами в поведінці, як дратівливість, упертість, які, в свою чергу, сприяють виникненню конфліктів у стосунках 3 товаришами, учителями. Психолог надавав провідного значення навколишньому середовищу у формуванні характеру «важкого» підлітка, але водночас зауважував, що характер дитини розвивається не так під впливом самого по собі навколишнього середовища, як під впливом відносин, які склалися в дитини із цим середовищем. Тобто, особливого значення набуває те, що дитина робить у своєму середовищі, чим у ньому цікавиться й чим захоплена (Фортунатов, 193). Отже, Г. А. Фортунатов, як і А. С. Макаренко, під моральною дефективністю розумів передусім порушення відносин дитини із середовищем існування.

Власне, коли проблема безпритульників втратила свою актуальність, а більшовицький уряд став дивитися на дитяче населення радше як на новий вид політичного суб'єкта (майбутнє покоління громадян соціалізму), приписування штампа «моральної дефективності» було засуджено як ідеологічно проблематичне, i від цього ярлика досить швидко позбулися, вважає Е. Байфорд (Байфорд, без дати).

До 1936 року - року прийняття так званої «сталінської конституції», яка проголошувала, що країна Рад успішно «досягла соціалізму», радянська політична еліта вирішила, що занадто багато радянських дітей були кваліфіковані педологами як «відстаючі від норми». Офіційним результатом цього рішення в липні 1936 року стала постанова партії «Про педологічні перекручення у системі наркомосів», яка скасовувала статус педології як авторитетної дисципліни, оголосивши іiі буржуазною й навіть фашистською «псевдонаукою», що одночасно накладало повну заборону на вживання поняття «морально дефективні» (Постанова Центрального Комітету ВКП(б) 1962). 31936 р. концепція «недосконалостей» обмежилася гранично вузькою концептуалізацією «дефекту» як індивідуальної вродженої недостатності, на противагу моделі, запропонованої «псевдонаукою» педологією, яка до цього визначала «недосконалості» як відхилення від норм для дитячого населення країни в цілому.

Висновки і перспективи подальших розвідок. Отже, аналіз поглядів відомих педагогів, психологів, педологів кінця XIX - початку XX ст. (I. А. Арямов, П. Г. Бельський, П. П. Блонський, Л. С. Виготський, В. П. Кащенко, Н. К. Крупська, А. С. Макаренко, В. Н. Сорока-Росинський, Н. Тарасевич, Г. Трошин, Г. А. Фортунатов та ін.) забезпечив можливість 
розкрити змістове наповнення поняття «морально дефективний» в психологопедагогічній науці досліджуваного періоду.

У радянській педагогіці до середини 20-х років XX ст. це поняття було офіційно визнаним і поширеним, ним характеризували дитину з поведінкою, що не відповідала нормам суспільної моралі. До категорії «дефективних» зараховували i малолітніх злочинців, i сотні тисяч безпритульних, які опинилися на вулиці унаслідок соціальних катаклізмів. «Морально дефективними» дітьми вважали велику й неоднорідну групу, представники якої відрізнялися від бажаної норми у своєму розвитку й поведінці.

Вітчизняні педагоги, психологи, педологи (П. Бельский, В. П. Кащенко й ін.) теорію моральної дефективності вважали біологізаторською за своєю суттю, відповідно до неї такі здібності, як засвоєння й виконання моральної норми визнавалися ними вродженими, а відхилення у поведінці, правопорушення розглядалися як результат генетично зумовлених дегенеративних процесів, що можуть посилюватися або ж послаблюватися під впливом навколишнього середовища.

Натомість, П. П. Блонський, Л. С. Виготський, Н. Тарасевич, В. Н. Сорока-Росинський й ін. розглядали моральність як складне явище, що має не біологічне, а соціальне коріння. Прихильники соціологізаторської теорії причини моральної дефективності пояснювали соціально-економічними та культурно-педагогічними умовами, у яких росла дитина. На думку цих вчених, емоційна неврівноваженість дітей, схильність до порушення законів і недисциплінованої поведінки визначались нездоровими умовами їх життя, зневагою до них 3 боку суспільства й іншими різноманітними взаємозалежними аномаліями навколишнього середовища. Психологічні проблеми таких дітей інтерпретувалися як наслідок стресів, що виникали в результаті війни, революції й радикальних змін, через які пройшло покоління дітей досліджуваного періоду.

На початку 30-х pp. XX ст. більшовицький уряд почав сприймати дитяче населення як новий вид політичного суб'єкта - майбутнє покоління громадян соціалізму, тому приписування штампа «моральної дефективності» було засуджено як ідеологічно проблематичне. У контексті державної політики, незалежно від біологізаторських чи соціологізаторських уподобань, учені практично припинили вживання поняття «морально дефективні» для позначення дітей з різноманітними порушеннями, натомість, почали активно використовувати поняття «важкі» діти.

Перспективи подальшого наукового пошуку вбачаємо у вивченні специфіки організації і діяльності відповідних спеціалізованих освітньовиховних закладів для дітей з різноманітними порушеннями.

\section{СПИСОК ВИКОРИСТАНИХ ДЖЕРЕЛ:}

Державний інститут розвитку сім'ї та молоді (2010). Становище сімей в Україні (за підсумками 2000-2009 років) : щчорічна державна доповідь Президентові Украӥни, Верховній Раді України, Кабінету Міністрів Украӥни про становище сімей та стан реалізаиї̈ державної сімейної політики. Київ. 227 с.

Раттер, М. (1987). Помощь трудным детям. Москва: Прогресс. 424 с.

Степанов, В. (2001). Психология трудных школьников: учеб. пособие. Москва: «Академия». $335 \mathrm{c}$. 
Шульга, Т. (1993). Методика работы с детьми «группь риска». Москва: Издат. УРАО. 104c.

Дічек, Н. (2013). А. С. Макаренко і проблема «морально дефективного дитинства» в ранньорадянський період. Рідна школа. № 1-2 (січень-лютий). с.15-22.

Янченко, Т. (2014). Педологія важкого дитинства у сучасних вимірах толерантності. Науковий вісник Миколаївського національного університету імені B. О. Сухомлинського [Текст] : зб. наук. праць. Миколаїв : МНУ ім. В. О. Сухомлинського. Вип. 1.47 (114) : Педагогічні науки / за ред. О. Я. Савченко, О. В. Сухомлинської. С. 335-342.

Байфорд, Э. (без даты). Субнорма и патология в истории российской науки о ребенке: к вопросу об отношении педологии и дефектологии в начале XX века [online]. Режим доступу на: http://fpp-mpsu.ru/uploads/all/allSWqVbbc37wIhTuiWuG3kW4mFIjK7IJ.pdf [Дата останнього звернення 24 травня 2019].

Блонский, П. (1923). О так называемой моральной дефективности. На путях $\kappa$ новой школе. № 9 [Електрон. ресурс]. Режим доступу: pedagogic.ru Дата останнього звернення 23 травня 2019].

Бельский, П. (1924). Исследование эмоииональной сферы несовершеннолетних, отклоняюшихся от нормы в своём поведении. Москва: Юрид. издательство, $90 \mathrm{c}$.

Кащенко, В. (2005). Нервность и дефективность в дошкольном и школьном возрасте. Москва: Школьная Пресса. 144 с.

Кащенко, В. (1992). Педагогическая коррекция: Исправление характера у детей и подростков. Москва: Просвещение. 223 с.

Грибоедов, А. (1924). Вопросы воспитания нормального и дефективного ребенка. Москва: Гос. изд-во. 232 с.

Трошин, Г. (1915). Антропологические основы воспитания. Сравнительная психология нормальных и ненормальных детей. [Петроград] : Школа-лечебница дра мед. Г. Я. Трошина, [1915]. Т. 2: Процессы чувства и воли. VIII, с. 405-959.

Тарасевич Н. (1922). Классификация дефективных детей. Харьков: Издание Главсоцвоса Н.К.П. 27 с.

Тарасевич, Н. (1924). Детская моральная дефективность. Наша школа. № 3. с. 48-52.

Выготский, Л. (1983a). Moral insanity. Выготский Л. С. Собрание сочинений: В 6-ти томах. Москва : «Педагогика». Т. 5. с. 150-152.

Выготский, Л. (1983b) Основные положения плана педагогической исследовательской работы в области трудного детства // Выготский Л. С. Собр. соч., 1983. Т. 5. С. $188-195$

Сорока-Росинский, В. (1991). Трудновоспитуемые. Педагогические соч. Москва : Педагогика. с. 137-152.

Крупская, Н. (1923). О так называемой моральной дефективности. На путях к новой школе. № 9. с.54-56.

Арямов, И. (1924). Рефлексология и педагогика. На путях к новой школе. № 3. c. $48-55$.

Макаренко, А. (1983). Тезисы доклада «Организация воспитания трудного детства». Педагогические соч. : в 8 m. Москва : Педагогика. Т 1. с. 53-54.

Фортунатов, Г. (1935). Трудные дети в семье и школе. Москва: Учпедгиз, 1935. $38 \mathrm{c}$.

Постанова Центрального Комітету ВКП(б), (1962). Про педологічні перекручення в системі Нарком осів. Керівні матеріали про школу. Київ : Рад. шк. c. $86-89$. 


\section{REFERENCES:}

Derzhavnyi instytut rozvytku simi ta molodi (2010). Stanovyshche simei v Ukraini (za pidsumkamy 2000-2009 rokiv) : shchorichna derzhavna dopovid Prezydentovi Ukrainy, Verkhovnii Radi Ukrainy, Kabinetu Ministriv Ukrainy pro stanovyshche simei ta stan realizatsii derzhavnoi simeinoi polityky. [The State of Families in Ukraine (in 20002009): Annual State Report to the President of Ukraine, the Verkhovna Rada of Ukraine, the Cabinet of Ministers of Ukraine on the Situation of Families and the State of Implementation of the State Family Policy] Kyiv. 227 s. [in Ukrainian].

Ratter. M. (1987). Pomoshch trudnym detyam. [Helping to Difficult Children]. Moskva: Progress. 424 s. [in Russian].

Stepanov, V. (2001). Psikhologiya trudnykh shkolnikov: ucheb. posobiye [Psychology of Difficult Schoolchildren: manual book] Moskva: "Akademiya". 335 s. [in Russian].

Shulga, T. (1993). Metodika raboty s detmi ,,gruppy riska” [Methods of working with Children "at Kisk”]. Moskva: Izdat. URAO. 104s. [in Russian].

Dichek, N. (2013). A. S. Makarenko i problema „moralno defektyvnoho dytynstva” v rannoradianskyi period [A.S. Makarenko and the Problem of "Morally Defective Childhood" in the Early Soviet Period]. Ridna shkola. No 1-2 (sichen-liutyi). s.15-22. [in Ukrainian].

Yanchenko, T. (2014). Pedolohiia vazhkoho dytynstva u suchasnykh vymirakh tolerantnosti [Pedology of Severe Childhood in Modern Dimensions of Tolerance.]. Naukovyi visnyk Mykolaivskoho natsionalnoho universytetu imeni V. O. Sukhomlynskoho [Tekst] : zb. nauk. prats. Mykolaiv : MNU im. V. O. Sukhomlynskoho. Vyp. 1.47 (114) : Pedahohichni nauky / za red. O. Ya. Savchenko, O. V. Sukhomlynskoi. S.335-342. [in Ukrainian].

Bayford. E. (bez daty). Subnorma i patologiya $v$ istorii rossiyskoy nauki o rebenke: $k$ voprosu ob otnoshenii pedologii $i$ defektologii $v$ nachale 20th veka [Subnorma and Pathology in the History of Russian Child Science: on the Relationship between Pedology and Defectology at the Beginning of the 20th century] [online]. Rezhim dostupu na: http://fpp-mpsu.ru/uploads/all/all-SWqVbbc37wIhTuiWuG3kW4mFIjK7IJ.pdf [Data ostannogo zvernennya 24 travnya 2019] [in Russian].

Blonskiy. P. (1923). O tak nazyvayemoy moralnoy defektivnosti [About the Socalled Moral Defectiveness]. Na putyakh k novoy shkole. № 9 [Elektron. resurs]. Rezhym dostupu: pedagogic.ru. Data ostannogo zvernennya 23 travnya 2019] [in Russian].

Belskiy. P. (1924). Issledovaniye emotsionalnoy sfery nesovershennoletnikh. otklonyayushchikhsya ot normy $v$ svoyem povedenii [The Study of the Emotional Sphere of teenagers Who Deviate from the Norm in Their Behavior]. Moskva: Yurid. izdatelstvo. 90 s. [in Russian].

Kashchenko. V. (2005). Nervnost i defektivnost $v$ doshkolnom $i$ shkolnom vozraste [Nervousness and Defectiveness in Preschool and School Age]. Moskva: Shkolnaya Pressa. 144 s. [in Russian].

Kashchenko. V. (1992). Pedagogicheskaya korrektsiya: Ispravleniye kharaktera u detey i podrostkov [Pedagogical Correction: Correction of Character in Children and teenagers]. Moskva: Prosveshcheniye. 223 s. [in Russian].

Griboyedova. A. (1924). Voprosy vospitaniya normalnogo i defektivnogo rebenka [Problems of Raising a Normal and Disabled Child]. Moskva: Gos. izd-vo. 232 s. [in Russian].

Troshyn. G. (1915). Antropologicheskiye osnovy vospitaniya [Anthropological Basis of Education. Comparative Psychology of Normal and Abnormal Children]. Sravnitelnaya psikhologiya normalnykh i nenormalnykh detey. [Petrograd] : Shkolalechebnitsa d-ra med. G. Ya. Troshina. [1915]. T. 2: Protsessy chuvstva i voli. VIII. s. 405-959. [in Russian]. 
Tarasevich N. (1922). Klassifikatsiya defektivnykh detey [Classification of Defective Children] Kharkov: Izdaniye Glavsotsvosa N.K.P. 27 s. [in Russian].

Tarasevich. N. (1924). Detskaya moralnaya defektivnost [Children's Moral Defectiveness]. Nasha shkola. No 3. s. 48-52. [in Russian].

Vygotskiy. L. (1983a). Moral insanity. Vygotskiy L. S. Sobraniye sochineniy: V 6ti tomakh. Moskva : "Pedagogika". T. 5. s. 150-152. [in Russian].

Vygotskiy. L. (1983b) Osnovnyye polozheniya plana pedagogicheskoy issledovatelskoy raboty v oblasti trudnogo detstva. [The Main Principles of the Plan of Pedagogical Research Work in the Field of Difficult Childhood] Sobr. soch. 1983. T. 5. S. 188-195. [in Russian].

Soroka-Rosinskiy, V. (1991). Trudnovospituyemyye [Difficult to Educate]. Pedagogicheskiye soch. Moskva : Pedagogika. s. 137-152. [in Russian].

Krupskaya. N. (1923). O tak nazyvayemoy moralnoy defektivnosti [On the Socalled Moral Defectiveness]. Na putyakh k novoy shkole. № 9. s.54-56. [in Russian].

Aryamov. I. (1924). Refleksologiya i pedagogika [Reflexology and Pedagogy]. Na putyakh k novoy shkole. No 3. s. 48-55. [in Russian].

Makarenko. A. (1983). Tezisy doklada „Organizatsiya vospitaniya trudnogo detstva" [Theses of the Report "Organization of Upbringing a Difficult Childhood"]. Pedagogicheskiye soch. : v 8 t. Moskva : Pedagogika. T 1. s. 53-54. [in Russian].

Fortunatov. G. (1935). Trudnyye deti v semye $i$ shkole [Difficult Children in the Family and School. Moskva: Uchpedgiz. 1935. 38 s. [in Russian].

Postanova Tsentralnoho Komitetu VKP (b), (1962). Pro pedolohichni perekruchennia v systemi Narkomosiv [Resolution of the Central Committee of the CPSU (b), (1962). On Pedological Distortions in the System of Narcomosiv]. Kerivni materialy pro shkolu. Kyiv : Rad. shk. s. 86-89. [in Ukrainian].

\title{
THE CONTENT OF THE CONCEPT "MORALLY DEFECTIVE" IN PSYCHOLOGICAL-PEDAGOGICAL SCIENCE AT THE END OF THE 19th - AT THE BEGINNING OF THE 20th CENTURY
}

\author{
Bondarets Maria \\ $\mathrm{PhD}$ student in the direction of 011 "Educational pedagogical sciences" \\ Rivne State University of the Humanities, \\ Rivne, Ukraine \\ ORCID: 0000-0001-9027-8652, \\ e-mail: maria_2812@ukr.net
}

\begin{abstract}
The content of the concept "morally defective" based on the analysis of the views of famous teachers, psychologists, pedologists of the end of the 19th - the beginning of the 20th century (I. Ariamov, P. Belskyi, P. Blonskyi, L. Vyhotskyi, V. Kashchenko, N. Krupska, A. Makarenko, V. Soroka-Rosynskyi, N. Tarasevych, H. Troshyn, H. Fortunatov, etc.) is revealed.

It was found that a child whose behavior did not meet the standards of public morality was characterized by the concept being studied. Both young criminals and hundreds of thousands of homeless who were in the street as a result of social cataclysms were ranked as "defective". A large and heterogeneous group of children, whose representatives differed from the desired norm in their development and behavior, were called "morally defective".

As Ukrainian teachers, psychologists, pedologists (P. Belskiy, V. Kashchenko, etc.) considered the theory of moral defectiveness to be biologizing in its essence, therefore, such abilities as assimilation and observance of the moral norm, were recognized by them as innate, and deviations in behavior, the offenses were regarded as the result of
\end{abstract}


genetically predisposed degenerative processes, that can be aggravated or weakened under the influence of the environment.

On the other hand, P. Blonskyi, L. Vyhotskyi, N. Tarasevych, V. Soroka-Rosynskyi and others considered morality as a complex phenomenon, having not biological, but social roots. Supporters of sociologizing theory explained the reasons for moral defectiveness by the socio-economic and cultural-pedagogical conditions in which the child was growing up. The psychological problems of such children were interpreted as a consequence of the stresses that arose as a result of the war, revolution and radical changes through which the generation of children of the studied period passed.

In the early 30 's of the 20th century in the context of state policy, scientists practically stopped using the notion of "morally defective" as ideologically problematic to refer to children with various disorders, instead, the concept of "difficult" children began to be actively used.

Key words: "morally defective", "moral insanity", "disabled" children, "difficult" children, biologizing theory, sociologizator theory.

Стаття надійшла до редакиії 15.04.2019 p. 